\title{
Quantum Mechanical Study on the Structure and Vibrational Spectra of Cyclobutanone and 1,2-Cyclobutanedione
}

\author{
Anoop kumar Pandey, Apoorva Dwivedi, and Neeraj Misra \\ Department of Physics, University of Lucknow, B 981, Sector-A, Mahanagar, Lucknow 226007, India \\ Correspondence should be addressed to Neeraj Misra; neerajmisra11@gmail.com
}

Received 13 June 2012; Revised 18 August 2012; Accepted 28 August 2012

Academic Editor: Tomasz Ruman

Copyright (C) 2013 Anoop kumar Pandey et al. This is an open access article distributed under the Creative Commons Attribution License, which permits unrestricted use, distribution, and reproduction in any medium, provided the original work is properly cited.

For 1,2-cyclobutanedione and cyclobutanone, we have carried out a comparative study of different methods like B3LYP, LSDA, and B3PW91 of DFT using 6-31G (d, p) basis set and MP2 method. On comparing these methods we find that B3PW91 method is closer to the experimental one. So by using B3PW91 method, we have made a comparative study of their structures, normal mode analysis, and other properties of the two derivatives of cyclobutane. The molecular HOMO, LUMO composition, their respective energy gaps, and MESP contours/surfaces have also been drawn to explain the activity of 1,2-cyclobutanedione and cyclobutanone.

\section{Introduction}

Ring Puckering vibrations in four membered molecules have drawn a lot of attention during recent times because of their low-frequency out-of-plane vibrations. In 1945, Bell predicted that the ring puckering vibration in four-member ring molecules should have a large quadratic term in its potential function which is the characteristic of cyclobutane [1]. As compared to linear butane molecules or larger hemicyclic alkenes such as cyclohexane, cyclobutane has strained carbon atoms and hence has greater bond energy. The chemical conformation of cyclobutane is not planar but folded or "puckered" [2]. One of the carbon atoms makes $25^{\circ}$ angle with the plane formed by the other three carbons. In this way some of the Hydrogen Eclipsing Interactions are reduced. The conformation is also known as a "Butterfly" [3]. In substituted cycloalkanes both planar and puckered conformations exist because the energy difference between the two states is small and they can interconvert. Despite inherent strain the cyclobutane motif is not found in linear shape in nature [4]. Density functional theory calculations are reported to provide excellent vibrational frequencies of organic compound if the calculated frequencies are scaled to compensate for the approximate treatment of electron correlation, basis set deficiencies, and for anharmonicity [5,
6]. A number of studies have been carried out regarding calculation of vibrational spectra by using DFT with 6$31 \mathrm{G}(\mathrm{d}, \mathrm{p})$ as basis set. Vibrational spectroscopy has the potential to yield valuable structural and conformational information of organic compounds, if used in conjugation with accurate quantum chemical calculations. Prediction of vibrational frequencies of polyatomic molecules by quantum chemical computation has become very popular because of its accurate and therefore consistent description of the experimental data. So, the aim of present study is to calculate the optimal geometry, thermodynamic properties, atomic charge distribution in gas phase, and vibrational analysis of both compounds. After analyzing these results some important aspects were noted about hydrogen bonding, reactivity, and stability of both the derivatives of cyclobutane. In this paper, the first aim is to investigate the performance of different density functional methods and Moller-Plesset method with a common basis set in predicting vibration spectra and geometry of the two molecules, namely, cyclobutane 1,2 dione and cyclobutanone. It can be very well stated that the hybrid functionals are the best density functional methods available for molecular calculations $[7,8]$. The hybrid functionals incorporate local exchange and correlation function with gradient correction and some components of Hartree Fock-like exchange functionals. A close agreement between 
the observed and calculated wave number is achieved by introducing the scaling factors. On comparing the various methods employed, the reliability of B3PW91 method with 6-31G (d, p) has been found to give the most accurate description of vibrational signatures in the present case. So, to simplify the discussion we have only discussed all the results using B3PW91 method.

\section{Computational Method}

The entire DFT calculations were performed at Pentium IV $(2.99 \mathrm{GHz})$ personal computer using the Gaussian 03 program package [9] utilizing gradient geometry optimization [10]. The vibrational frequencies associated with ground state optimized geometry have been evaluated with different level of theories and 6-31G $(\mathrm{d}, \mathrm{p})$ as the basis set. Combined use of B3LYP, LSDA, B3PW91, and MP2 with split valence basis set 6-31G $(d, p)$ shows an excellent compromise between accuracy and computational efficiency of vibrational spectra of large and medium molecules. The structures of 1,2cyclobutanedione and cyclobutanone are modeled and then geometry optimization has been done until it reaches to local minima after that vibrational mode is calculated. The vibrational frequencies for these molecules were calculated with these methods and then scaled [11] by 0.9613 above 800 and by 1.0013 below 800 , respectively. The assignment of the calculated normal modes has been made on the basis of the corresponding true potential energy distribution (PED). The PED is computed from the calculated vibrational frequencies using VEDA program [12]. Gauss View 3.0 program [13] has been considered to get visual animation.

\section{Results and Discussion}

3.1. Geometry Optimizations Employing Various Methods at 6-31G $(d, p)$ Basis Set. The optimized structure parameters of 1,2-cyclobutanedione and cyclobutanone calculated by B3LYP, B3PW91, LSDA, and MP2 methods with the 6-31G $(\mathrm{d}, \mathrm{p})$ basis set are listed in Table 1 and are in accordance with the atom numbering scheme as shown in Figures 1 and 2, respectively. After geometry optimization local minimum energy obtained for structure optimization of 1,2cyclobutanedione with 6-31G $(\mathrm{d}, \mathrm{p})$ basis set is approximately -305.1210 a.u. for both B3LYP [14-18] and B3PW91 methods but -303.6130 a.u. for LSDA method. The minimal energy is found to be approximately -304.3680 a.u. for MP2 level of theory. The local minimum energy obtained for structure optimization of cyclobutanone with 6-31G $(\mathrm{d}, \mathrm{p})$ basis set is approximately -231.1500 a.u. for B3PW91 approaches. The difference in energies between these two molecules is about 73.9710 a.u. for B3PW91 methods. This drift in energy is observed due to the disubstitution of oxygen on the cycloring which increases the repulsion between oxygen in the case of 1,2-cyclobutanedione.

The 1,2-cyclobutanedione molecule has a point group symmetry, that is, $C_{2 v}$; however, cyclobutanone has a point group symmetry $C_{s}$. In both the molecules no hydrogen atoms of each methylene unit lie in the plane of ring but

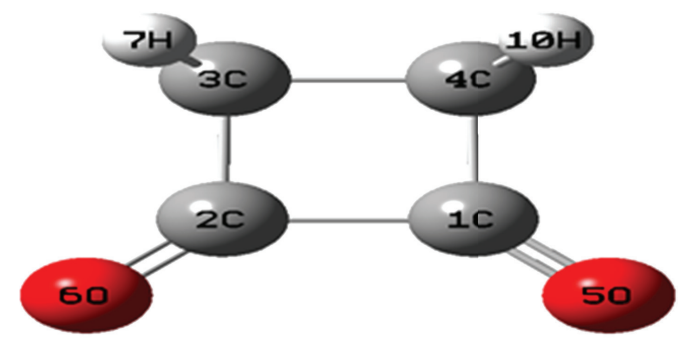

FIGURE 1: Model molecular structure of 1,2-cyclobutanedione.

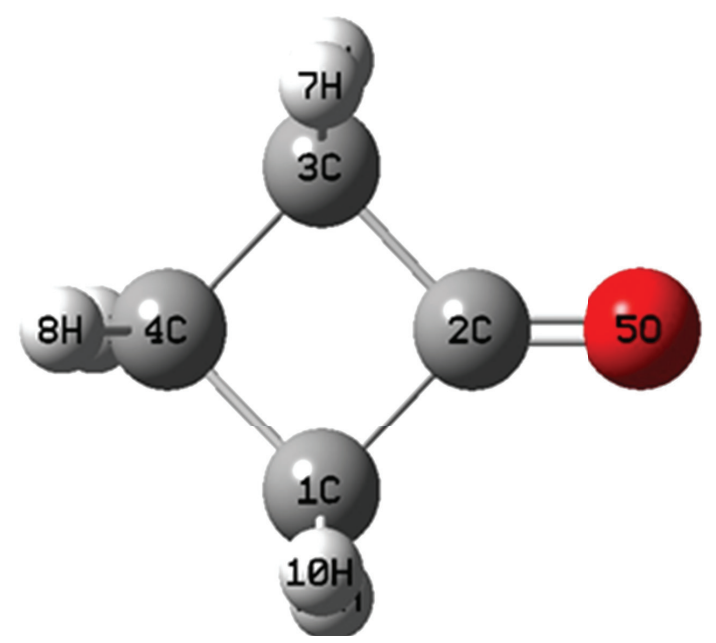

FIGURE 2: Model molecular structure of cyclobutanone.

are symmetrically positioned above and below this plane. As discussed earlier, the configuration of both the molecules in the ground state corresponds to $C_{2 \mathrm{v}}$ symmetry; the optimized bond parameters of both molecules calculated by various methods are listed in Table 2.

The atomic numbering used in defining the structural parameters for 1,2-cyclobutanedione is illustrated in Figure 1. The $\mathrm{C}-\mathrm{C}$ bond distances of the title compound are found to have higher values in case of B3LYP and B3PW91 calculation with respect to those by LSDA computation. All these $\mathrm{C}-\mathrm{C}$ bond lengths are in good agreement with the available microwave data of similar types of molecules [19-22]. The $\mathrm{C}-\mathrm{O}$ bonds of the oxygen attached to the ring show significant elongation for B3PW91 method. The $\mathrm{C} 1-\mathrm{C} 4$ and $\mathrm{C} 4-\mathrm{C} 3$ bond lengths in cyclobutanone and 1,2cyclobutanedione bond are $1.55 \AA, 1.55 \AA$ and $1.54 \AA$, $1.55 \AA$, respectively. The observed difference of $.01 \AA$ between the $\mathrm{C}-\mathrm{C}$ bond lengths seems to be normal which is equal to the difference of $\mathrm{sp}^{3}-\mathrm{sp}^{3}$ and $\mathrm{sp}^{3}-\mathrm{sp}^{2}$ carbon-carbon single bond lengths. Similar differences between $\mathrm{sp}^{3}-\mathrm{sp}^{3}$ and $s \mathrm{p}^{3}-\mathrm{sp}^{2}$ and $\mathrm{sp}^{2}-\mathrm{sp}^{2} \mathrm{C}-\mathrm{C}$ single bond lengths have been observed between propane $r(\mathrm{C}-\mathrm{C})=1.532 \AA[13]$ propane $r(\mathrm{C}-\mathrm{C})=1.505 \AA$ [13] and acetaldehyde $r(\mathrm{C}-\mathrm{C})=1.514 \AA$ [23].

The average $\mathrm{C}-\mathrm{C}$ bond length is $r(\mathrm{C}-\mathrm{C})_{\mathrm{av}}=1.55 \AA$, $1.55 \AA$ in cyclobutanone and 1,2-cyclobutanedione respectively, while it is about $.02 \AA$ longer than the corresponding 
TABLE 1: Bond lengths ( $\mathrm{A})$ and bond angle of 1,2-cyclobutanedione and cyclobutanone.

\begin{tabular}{|c|c|c|c|c|c|c|c|}
\hline \multicolumn{2}{|c|}{ Cyclobutanone } & \multicolumn{6}{|c|}{ Cyclobutane 1,2-dione } \\
\hline \multirow{2}{*}{ Parameters } & \multirow{2}{*}{$\begin{array}{l}\text { Theoretical values } \\
\text { B3PW91/6-31G (d,p) }\end{array}$} & \multirow{2}{*}{ Parameters } & \multirow{2}{*}{$\begin{array}{l}\text { Exp. data } \\
\text { (X-Ray data) }\end{array}$} & \multicolumn{4}{|c|}{ Theoretical values } \\
\hline & & & & $\begin{array}{c}\text { B3LYP/6-31G } \\
(\mathrm{d}, \mathrm{p})\end{array}$ & $\begin{array}{c}\text { B3PW91/6-31G } \\
(\mathrm{d}, \mathrm{p})\end{array}$ & $\begin{array}{c}\mathrm{MP} 2 / 6-31 \mathrm{G} \\
(\mathrm{d}, \mathrm{p})\end{array}$ & $\begin{array}{c}\text { LSDA/6-31G } \\
(\mathrm{d}, \mathrm{p})\end{array}$ \\
\hline \multicolumn{8}{|c|}{ Bond lengths } \\
\hline $\mathrm{C} 1-\mathrm{C} 2$ & 1.53 & $\mathrm{C} 1-\mathrm{C} 2$ & 1.561 & 1.58 & 1.58 & 1.57 & 1.57 \\
\hline $\mathrm{C} 1-\mathrm{C} 4$ & 1.55 & $\mathrm{C} 1-\mathrm{C} 4$ & 1.524 & 1.55 & 1.54 & 1.55 & 1.53 \\
\hline $\mathrm{C} 1-\mathrm{H} 10$ & 1.10 & $\mathrm{C} 1=\mathrm{O} 5$ & 1.19 & 1.20 & 1.20 & 1.21 & 1.20 \\
\hline $\mathrm{C} 1-\mathrm{H} 11$ & 1.09 & $\mathrm{C} 2-\mathrm{C} 3$ & 1.52 & 1.55 & 1.54 & 1.55 & 1.53 \\
\hline $\mathrm{C} 2-\mathrm{C} 3$ & 1.53 & $\mathrm{C} 2=\mathrm{O} 6$ & 1.196 & 1.20 & 1.20 & 1.21 & 1.20 \\
\hline $\mathrm{C} 2=\mathrm{O} 5$ & 1.20 & $\mathrm{C} 3-\mathrm{C} 4$ & 1.54 & 1.55 & 1.55 & 1.54 & 1.53 \\
\hline $\mathrm{C} 3-\mathrm{C} 4$ & 1.55 & $\mathrm{C} 3-\mathrm{H} 7$ & 0.99 & 1.09 & 1.09 & 1.09 & 1.10 \\
\hline $\mathrm{C} 3-\mathrm{H} 6$ & 1.09 & $\mathrm{C} 3-\mathrm{H} 8$ & 0.99 & 1.09 & 1.09 & 1.09 & 1.10 \\
\hline $\mathrm{C} 3-\mathrm{H} 7$ & 1.10 & C4-H9 & 0.99 & 1.09 & 1.09 & 1.09 & 1.10 \\
\hline $\mathrm{C} 4-\mathrm{H} 8$ & 1.09 & $\mathrm{C} 4-\mathrm{H} 10$ & 0.99 & 1.09 & 1.09 & 1.09 & 1.10 \\
\hline $\mathrm{C} 4-\mathrm{H} 9$ & 1.09 & $\mathrm{C} 2-\mathrm{C} 1-\mathrm{C} 4$ & 89.5 & 89.42 & 89.40 & 89.42 & 89.32 \\
\hline \multicolumn{8}{|c|}{ Bond angles } \\
\hline $\mathrm{C} 2-\mathrm{C} 1-\mathrm{C} 4$ & 88.19 & $\mathrm{C} 2-\mathrm{C} 1=\mathrm{O} 5$ & 134.26 & 135.32 & 135.40 & 135.38 & 135.54 \\
\hline $\mathrm{C} 2-\mathrm{C} 1-\mathrm{H} 10$ & 112.46 & $\mathrm{C} 4-\mathrm{C} 1=\mathrm{O} 5$ & 136.23 & 135.25 & 135.20 & 135.20 & 135.14 \\
\hline $\mathrm{C} 2-\mathrm{C} 1-\mathrm{H} 11$ & 114.89 & $\mathrm{C} 1-\mathrm{C} 2-\mathrm{C} 3$ & 89.7 & 89.42 & 89.40 & 89.42 & 89.32 \\
\hline $\mathrm{C} 4-\mathrm{C} 1-\mathrm{H} 10$ & 114.90 & $\mathrm{C} 1-\mathrm{C} 2=\mathrm{O} 6$ & 134.07 & 135.32 & 135.40 & 135.38 & 135.54 \\
\hline $\mathrm{C} 4-\mathrm{C} 1-\mathrm{H} 11$ & 117.34 & $\mathrm{C} 3-\mathrm{C} 2=\mathrm{O} 6$ & 136.21 & 135.25 & 135.20 & 135.20 & 135.14 \\
\hline $\mathrm{H} 10-\mathrm{C} 1-\mathrm{H} 11$ & 108.12 & $\mathrm{C} 2-\mathrm{C} 3-\mathrm{C} 4$ & 90.44 & 90.58 & 90.60 & 90.58 & 90.68 \\
\hline $\mathrm{C} 1-\mathrm{C} 2-\mathrm{C} 3$ & 92.35 & $\mathrm{C} 2-\mathrm{C} 3-\mathrm{H} 7$ & 113.6 & 112.77 & 112.75 & 112.63 & 112.68 \\
\hline $\mathrm{C} 1-\mathrm{C} 2=\mathrm{O} 5$ & 133.81 & $\mathrm{C} 2-\mathrm{C} 3-\mathrm{H} 8$ & 113.6 & 112.77 & 112.75 & 112.63 & 112.68 \\
\hline $\mathrm{C} 3-\mathrm{C} 2=\mathrm{O} 5$ & 133.81 & $\mathrm{C} 4-\mathrm{C} 3-\mathrm{H} 7$ & 113.6 & 115.67 & 115.73 & 115.56 & 116.10 \\
\hline $\mathrm{C} 2-\mathrm{C} 3-\mathrm{C} 4$ & 88.19 & $\mathrm{C} 4-\mathrm{C} 3-\mathrm{H} 8$ & 113.6 & 115.67 & 115.73 & 115.56 & 116.10 \\
\hline $\mathrm{C} 2-\mathrm{C} 3-\mathrm{H} 6$ & 114.87 & $\mathrm{H} 7-\mathrm{C} 3-\mathrm{H} 8$ & 110.8 & 108.55 & 108.48 & 108.95 & 107.91 \\
\hline $\mathrm{C} 2-\mathrm{C} 3-\mathrm{H} 7$ & 112.44 & $\mathrm{C} 1-\mathrm{C} 4-\mathrm{C} 3$ & 90.33 & 90.58 & 90.60 & 90.58 & 90.68 \\
\hline $\mathrm{C} 4-\mathrm{C} 3-\mathrm{H} 6$ & 117.37 & $\mathrm{C} 1-\mathrm{C} 4-\mathrm{H} 9$ & 113.6 & 112.77 & 112.75 & 112.63 & 112.68 \\
\hline $\mathrm{C} 4-\mathrm{C} 3-\mathrm{H} 7$ & 114.94 & $\mathrm{C} 1-\mathrm{C} 4-\mathrm{H} 10$ & 113.6 & 112.77 & 112.75 & 112.63 & 112.68 \\
\hline $\mathrm{H} 6-\mathrm{C} 3-\mathrm{H} 7$ & 108.11 & $\mathrm{C} 3-\mathrm{C} 4-\mathrm{H} 9$ & 113.6 & 115.67 & 115.73 & 115.56 & 116.10 \\
\hline $\mathrm{C} 1-\mathrm{C} 4-\mathrm{C} 3$ & 90.80 & C3-C4-H10 & 113.6 & 115.67 & 115.73 & 115.56 & 116.10 \\
\hline $\mathrm{C} 1-\mathrm{C} 4-\mathrm{H} 8$ & 115.12 & H9-C4-H10 & 110.9 & 108.55 & 108.48 & 108.95 & 107.91 \\
\hline $\mathrm{C} 1-\mathrm{C} 4-\mathrm{H} 9$ & 113.26 & $\mathrm{C} 4-\mathrm{C} 1-\mathrm{C} 2-\mathrm{C} 3$ & 1.12 & 0.00 & 0.00 & 0.00 & 0.00 \\
\hline $\mathrm{C} 3-\mathrm{C} 4-\mathrm{H} 8$ & 115.15 & $\mathrm{C} 4-\mathrm{C} 1-\mathrm{C} 2=\mathrm{O} 6$ & -177.2 & 180.01 & 180.01 & 180.00 & 180.00 \\
\hline C3-C4-H9 & 113.26 & $\mathrm{O} 5=\mathrm{C} 1-\mathrm{C} 2-\mathrm{C} 3$ & -178 & -180.01 & -180.01 & -180.01 & -180.00 \\
\hline $\mathrm{H} 8-\mathrm{C} 4-\mathrm{H} 9$ & 108.55 & $\mathrm{O} 5=\mathrm{C} 1-\mathrm{C} 2=\mathrm{O} 6$ & 3.7 & 0.00 & 0.00 & 0.00 & 0.00 \\
\hline \multicolumn{8}{|c|}{ Dihedral angles } \\
\hline $\mathrm{C} 4-\mathrm{C} 1-\mathrm{C} 2-\mathrm{C} 3$ & 5.23 & $\mathrm{C} 2-\mathrm{C} 1-\mathrm{C} 4-\mathrm{C} 3$ & -1.11 & 0.00 & 0.00 & 0.00 & 0.00 \\
\hline $\mathrm{C} 4-\mathrm{C} 1-\mathrm{C} 2=\mathrm{O} 5$ & -172.93 & $\mathrm{C} 2-\mathrm{C} 1-\mathrm{C} 4-\mathrm{H} 9$ & & -118.30 & -118.37 & -118.14 & -118.80 \\
\hline $\mathrm{H} 10-\mathrm{C} 1-\mathrm{C} 2-\mathrm{C} 3$ & -111.05 & $\mathrm{C} 2-\mathrm{C} 1-\mathrm{C} 4-\mathrm{H} 10$ & & 118.30 & 118.37 & 118.14 & 118.80 \\
\hline $\mathrm{H} 10-\mathrm{C} 1-\mathrm{C} 2=\mathrm{O} 5$ & 70.79 & $\mathrm{O} 5=\mathrm{C} 1-\mathrm{C} 4-\mathrm{C} 3$ & 178 & 180.01 & 180.01 & 180.01 & 180.00 \\
\hline $\mathrm{H} 11-\mathrm{C} 1-\mathrm{C} 2-\mathrm{C} 3$ & 124.70 & $\mathrm{O} 5=\mathrm{C} 1-\mathrm{C} 4-\mathrm{H} 9$ & & 61.71 & 61.64 & 61.87 & 61.21 \\
\hline $\mathrm{H} 11-\mathrm{C} 1-\mathrm{C} 2=\mathrm{O} 5$ & -53.46 & $\mathrm{O} 5=\mathrm{C} 1-\mathrm{C} 4-\mathrm{H} 10$ & & -61.69 & -61.62 & -61.85 & -61.20 \\
\hline $\mathrm{C} 2-\mathrm{C} 1-\mathrm{C} 4-\mathrm{C} 3$ & -5.16 & $\mathrm{C} 1-\mathrm{C} 2-\mathrm{C} 3-\mathrm{C} 4$ & -1.11 & 0.00 & 0.00 & 0.00 & 0.00 \\
\hline $\mathrm{C} 2-\mathrm{C} 1-\mathrm{C} 4-\mathrm{H} 8$ & -123.58 & $\mathrm{C} 1-\mathrm{C} 2-\mathrm{C} 3-\mathrm{H} 7$ & & -118.30 & -118.37 & -118.14 & -118.80 \\
\hline $\mathrm{C} 2-\mathrm{C} 1-\mathrm{C} 4-\mathrm{H} 9$ & 110.69 & $\mathrm{C} 1-\mathrm{C} 2-\mathrm{C} 3-\mathrm{H} 8$ & & 118.30 & 118.37 & 118.14 & 118.80 \\
\hline $\mathrm{H} 10-\mathrm{C} 1-\mathrm{C} 4-\mathrm{C} 3$ & 108.84 & $\mathrm{O} 6=\mathrm{C} 2-\mathrm{C} 3-\mathrm{C} 4$ & -177.2 & -180.01 & -180.01 & -180.00 & -180.00 \\
\hline
\end{tabular}


TABLE 1: Continued.

\begin{tabular}{|c|c|c|c|c|c|c|c|}
\hline \multicolumn{2}{|c|}{ Cyclobutanone } & \multicolumn{6}{|c|}{ Cyclobutane 1,2-dione } \\
\hline \multirow{2}{*}{ Parameters } & \multirow{2}{*}{$\begin{array}{l}\text { Theoretical values } \\
\text { B3PW91/6-31G }(\mathrm{d}, \mathrm{p})\end{array}$} & \multirow{2}{*}{ Parameters } & \multirow{2}{*}{$\begin{array}{l}\text { Exp. data } \\
\text { (X-Ray data) }\end{array}$} & \multicolumn{4}{|c|}{ Theoretical values } \\
\hline & & & & $\begin{array}{c}\text { B3LYP/6-31G } \\
(\mathrm{d}, \mathrm{p})\end{array}$ & $\begin{array}{c}\text { B3PW91/6-31G } \\
(\mathrm{d}, \mathrm{p})\end{array}$ & $\begin{array}{c}\mathrm{MP} 2 / 6-31 \mathrm{G} \\
(\mathrm{d}, \mathrm{p})\end{array}$ & $\begin{array}{c}\text { LSDA/6-31G } \\
(\mathrm{d}, \mathrm{p})\end{array}$ \\
\hline $\mathrm{H} 10-\mathrm{C} 1-\mathrm{C} 4-\mathrm{H} 8$ & -9.58 & $\mathrm{O} 6=\mathrm{C} 2-\mathrm{C} 3-\mathrm{H} 7$ & & 61.69 & 61.62 & 61.86 & 61.20 \\
\hline $\mathrm{H} 10-\mathrm{C} 1-\mathrm{C} 4-\mathrm{H} 9$ & -135.31 & $\mathrm{O} 6=\mathrm{C} 2-\mathrm{C} 3-\mathrm{H} 8$ & & -61.71 & -61.64 & -61.86 & -61.21 \\
\hline $\mathrm{H} 11-\mathrm{C} 1-\mathrm{C} 4-\mathrm{C} 3$ & -122.39 & $\mathrm{C} 2-\mathrm{C} 3-\mathrm{C} 4-\mathrm{C} 1$ & 1.14 & 0.00 & 0.00 & 0.00 & 0.00 \\
\hline $\mathrm{H} 11-\mathrm{C} 1-\mathrm{C} 4-\mathrm{H} 8$ & 119.19 & $\mathrm{C} 2-\mathrm{C} 3-\mathrm{C} 4-\mathrm{H} 9$ & & 115.74 & 115.74 & 115.56 & 115.80 \\
\hline $\mathrm{H} 11-\mathrm{C} 1-\mathrm{C} 4-\mathrm{H} 9$ & -6.55 & $\mathrm{C} 2-\mathrm{C} 3-\mathrm{C} 4-\mathrm{H} 10$ & & -115.74 & -115.74 & -115.56 & -115.80 \\
\hline $\mathrm{C} 1-\mathrm{C} 2-\mathrm{C} 3-\mathrm{C} 4$ & -5.23 & $\mathrm{H} 7-\mathrm{C} 3-\mathrm{C} 4-\mathrm{C} 1$ & & 115.74 & 115.74 & 115.56 & 115.80 \\
\hline $\mathrm{C} 1-\mathrm{C} 2-\mathrm{C} 3-\mathrm{H} 6$ & -124.72 & $\mathrm{H} 7-\mathrm{C} 3-\mathrm{C} 4-\mathrm{H} 9$ & & -128.52 & -128.52 & -128.88 & -128.40 \\
\hline $\mathrm{C} 1-\mathrm{C} 2-\mathrm{C} 3-\mathrm{H} 7$ & 111.09 & $\mathrm{H} 7-\mathrm{C} 3-\mathrm{C} 4-\mathrm{H} 10$ & & 0.00 & 0.00 & 0.00 & 0.00 \\
\hline $\mathrm{O} 5=\mathrm{C} 2-\mathrm{C} 3-\mathrm{C} 4$ & 172.93 & $\mathrm{H} 8-\mathrm{C} 3-\mathrm{C} 4-\mathrm{C} 1$ & & -115.74 & -115.74 & -115.56 & -115.80 \\
\hline $\mathrm{O} 5=\mathrm{C} 2-\mathrm{C} 3-\mathrm{H} 6$ & 53.44 & $\mathrm{H} 8-\mathrm{C} 3-\mathrm{C} 4-\mathrm{H} 9$ & & 0.00 & 0.00 & 0.00 & 0.00 \\
\hline $\mathrm{O} 5=\mathrm{C} 2-\mathrm{C} 3-\mathrm{H} 7$ & -70.76 & $\mathrm{H} 8-\mathrm{C} 3-\mathrm{C} 4-\mathrm{H} 10$ & & 128.51 & 128.52 & 128.88 & 128.40 \\
\hline $\mathrm{C} 2-\mathrm{C} 3-\mathrm{C} 4-\mathrm{C} 1$ & 5.16 & & & & & & \\
\hline $\mathrm{C} 2-\mathrm{C} 3-\mathrm{C} 4-\mathrm{H} 8$ & 123.55 & & & & & & \\
\hline $\mathrm{C} 2-\mathrm{C} 3-\mathrm{C} 4-\mathrm{H} 9$ & -110.69 & & & & & & \\
\hline $\mathrm{H} 6-\mathrm{C} 3-\mathrm{C} 4-\mathrm{C} 1$ & 122.38 & & & & & & \\
\hline $\mathrm{H} 6-\mathrm{C} 3-\mathrm{C} 4-\mathrm{H} 8$ & -119.22 & & & & & & \\
\hline $\mathrm{H} 6-\mathrm{C} 3-\mathrm{C} 4-\mathrm{H} 9$ & 6.53 & & & & & & \\
\hline $\mathrm{H} 7-\mathrm{C} 3-\mathrm{C} 4-\mathrm{C} 1$ & -108.82 & & & & & & \\
\hline $\mathrm{H} 7-\mathrm{C} 3-\mathrm{C} 4-\mathrm{H} 8$ & 9.57 & & & & & & \\
\hline $\mathrm{H} 7-\mathrm{C} 3-\mathrm{C} 4-\mathrm{H} 9$ & 135.33 & & & & & & \\
\hline
\end{tabular}

TABLE 2: Symmetry in molecule at global minimum energy of 1,2-cyclobutanedione and cyclobutanone.

\begin{tabular}{|c|c|c|c|}
\hline Molecule & Method & Initial symmetry & Higher order point symmetry \\
\hline Cyclobutanone & B3PW91 & $\mathrm{C}_{1}$ & $\mathrm{C}_{\mathrm{s}}$ \\
\hline \multirow{4}{*}{ Cyclobutane 1,2-dione } & LSDA & $\mathrm{C}_{\mathrm{s}}$ & $\mathrm{C}_{2 \mathrm{v}}$ \\
\hline & MP2 & $\mathrm{C}_{\mathrm{s}}$ & $\mathrm{C}_{2 \mathrm{v}}$ \\
\hline & B3LYP & $\mathrm{C}_{2}$ & $\mathrm{C}_{2 \mathrm{v}}$ \\
\hline & B3PW91 & $\mathrm{C}_{2}$ & $\mathrm{C}_{2 \mathrm{v}}$ \\
\hline
\end{tabular}

bond in ethane (1.53 $\AA$ ) [24] and in higher n-alkynes $1.53 \AA$, $1.53 \AA[19-22]$ but almost equal to the C-C bond length in cyclobutane $(1.55 \AA)$ [24].

In case of LSDA method calculated bond lengths of $\mathrm{C}-\mathrm{H}$ are $0.11 \AA$ A larger than the experimental value. As discussed in literature [14], it is well known that B3LYP methods predict bond lengths, which are systematically too long, particularly $\mathrm{C}-\mathrm{H}$ bond lengths. Large deviation from experimental $\mathrm{C}-\mathrm{H}$ bond lengths may arise from the low scattering factors of hydrogen atoms in the X-ray diffraction [15-18]. However, B3LYP, B3PW91, and MP2 yield the corresponding bond lengths close to experimental results than LSDA one. The calculated bond distances vary from one method to another. The bond distances calculated by B3LYP and B3PW91 are comparable to each other and also in agreement with the available data. The bond angles calculated using various methods do not show any significant variation. Substitution of a trigonal carbon atom in the place of tetrahedral ring carbon atom increases the ring strain because the unstrained $\mathrm{sp}^{2}$ valence angle is $120^{\circ}$ as compared to the $\mathrm{sp}^{3}$ unstrained valence angle of $109^{\circ}$. Hence the shape is deformed. However, from this calculation of the structural parameters it is not possible to assess the superiority of one method over the others in predicting the geometrical structure of these molecules because of lack of experimental values for a direct comparison. For geometrical data of cyclobutanone and 1,2-cyclobutanedione, good agreement between theory and experiment is obtained for the MP2 and B3LYP, B3PW91, LSDA levels with basis sets including diffuse functions. Perhaps the best method of optimization of both compounds should be decided from frequency calculation. The optimized structure of 1,2-cyclobutanedione molecules following B3PW91/6-31G (d, p) method is shown in Figure 1, as this technique yields the scaled vibrational wave numbers which 


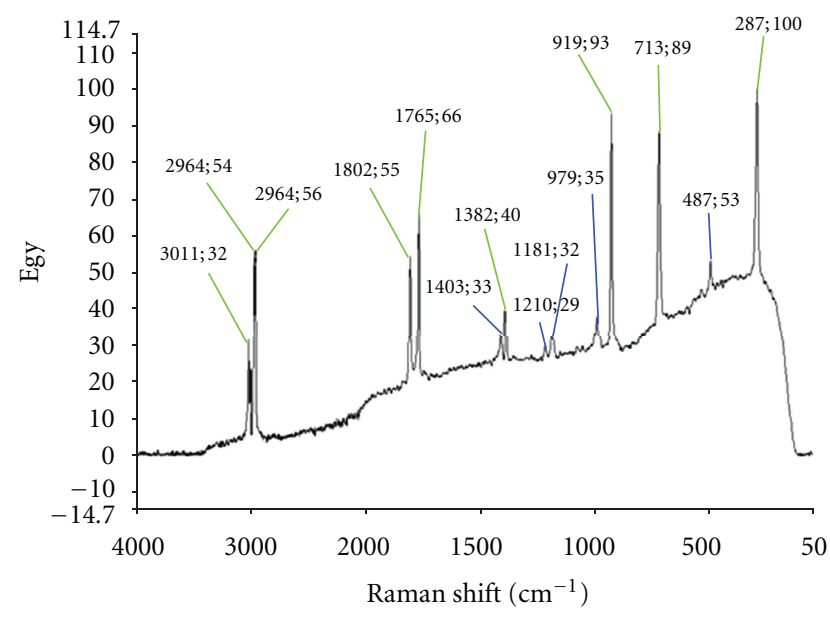

FIGURE 3: Raman spectra of 1,2-cyclobutanedione.

is in best agreement with the experimental observations. So to sort out the complication we have discussed the PED of B3PW91/6-31G (d, p) only. The optimized geometries of 1,2cyclobutanedione are in good agreement with X-Ray data [25] given in Table 1.

3.2. Thermodynamic Properties. Several calculated thermodynamic properties based on the vibrational analysis at B3LYP, B3PW91, LSDA, and MP2/6-31G (d, p) level, like internal thermal energy $(E)$, constant volume heat capacity $\mathrm{C}_{\mathrm{v}}$, and entropy $S$, have been calculated and listed in Table 3. At the room temperature, conduction band is almost empty so electronic contribution in total energy is negligible. Thermodynamic parameters clearly indicate that vibration motion plays a crucial role in assessing thermodynamical behavior of title compounds. As seen in Table 4 total thermal energy calculated with B3LYP, B3PW91 gave nearly the same result. The dipole moment of the cyclobutanone and 1,2-cyclobutanedione molecules was computed at the different levels of theory. The calculated dipole moments at B3PW91/6-31G (d, p) level are 3.7 D for 1,2cyclobutanedione and $2.84 \mathrm{D}$ for cyclobutanone, respectively. So, probably cyclobutane 1,2-dione is a better solvent than cyclobutanone. This is due to the disubstituted oxygen on ring, which creates more polarity than the monosubstituted oxygen.

The sum of the thermal energy in cyclobutanone is higher than that of the corresponding 1,2-cyclobutanedione. The heat capacity of the 1,2-cyclobutanedione is increased due to the extragenerated hydrogen bond. Entropy of cyclobutanone molecule is $72 \mathrm{Cal} / \mathrm{Mol}-\mathrm{Kel}$ in which is smaller than entropy of 1,2-cyclobutanedione $75.133 \mathrm{Cal} / \mathrm{Mol}-\mathrm{Kelvin}$, and hence most probably cyclobutanone has a well-ordered structure than 1,2-cyclobutanedione. As it has been earlier discussed that cyclobutanone deforms more to the planarity than 1,2-cyclobutanedione, so according to MO theory, molecular orbitals are not strongly overlapped in case of 1,2cyclobutanedione. Hence, bond strength is weaker in case of 1,2-cyclobutanedione and requires lesser energy to break these bonds than cyclobutanone. So, 1,2-cyclobutanedione is more reactive than the other one. This feature is also supported by Homo-Lumo gap in which this gap is smaller than in the case of 1,2-cyclobutanedione.

3.3. Atomic Charge Distribution in Gas Phase. The Mulliken atomic charges for all the atoms of the 1,2-cyclobutanedione and cyclobutanone compounds are calculated by B3LYP, B3PW91, LSDA, and MP2 methods with 6-31G (d, p) as basis set in gas phase and are presented in Table 4. To clarify the nature of both the molecules NBO and Mulliken, analyses were carried out. Table 3 gives the natural atomic charges of cyclobutanone and diones. As we see from Figures 1 and 2, oxygen is more electronegative; hence it extracts electron from $1 \mathrm{C}$ and $2 \mathrm{C}$ in case of 1,2-cyclobutanedione and $2 \mathrm{C}$ in case of cyclobutanone, respectively, and as a result carbon becomes positively charged. However, 3C and 4C are more electronegative. Hence, they extract electron from the hydrogen and gain negative charge on these carbons in case of 1,2-cyclobutanedione. In case of cyclobutanone 3C, $1 \mathrm{C}, 4 \mathrm{C}$, are more electronegative than hydrogen and hence acquire negative charges. As seen from Table 3, the oxygen atoms have bigger negative atomic charges, suggesting that they are potential sites to react with charged moieties/ions. This can possibly provide further insight into the interactions between the potentially interacting oxygen with hydrogen of methylene group with other molecules.

3.4. Assignment of Fundamentals. 1,2-cyclobutanedione has 10 atoms with 24 normal modes of vibration while cyclobutanone has 11 atoms with 27 normal modes of vibrations. On the basis of our calculations and the reported FT-Raman spectra [26], we made a reliable one-to-one correspondence between the fundamentals and the frequencies calculated by DFT (B3LYP, B3PW91, LSDA) and MP2 methods. On the basis of theoretical investigation as discussed earlier the point group of 1,2-cyclobutanedione and cyclobutanone molecule is considered as $\mathrm{C}_{2 \mathrm{v}}$. Based on such assumption, the normal modes of vibration arising from 1,2-cyclobutanedione and cyclobutanone can be divided between two different symmetry species as $8 \mathrm{a} 1+5 \mathrm{a} 2+4 \mathrm{~b} 1+7 \mathrm{~b} 2$ and $9 \mathrm{a} 1+4 \mathrm{a} 2$ $+7 \mathrm{~b} 1+7 \mathrm{~b} 2$, respectively. The scaled vibrational signatures using all other methods are also presented. In these cases the assignments are done following the animated view of normal mode description. A good agreement between the theoretical and experimental is observed. The relative band intensities are also very satisfactory along with their positions. Some important modes are discussed hereafter. The harmonic-vibrational frequencies are calculated for both the molecules, and experimental frequencies (FT Raman) have been compared in Tables 5 and 6 for 1,2-cyclobutanedione and cyclobutanone, respectively (Figure 3 ).

\subsection{Vibrational Modes Description}

3.5.1. C-H Vibrations. The asymmetric $\mathrm{C}-\mathrm{H}$ stretching vibrations are generally observed in the region 3100$3000 \mathrm{~cm}^{-1}$, while the symmetric stretch appears between 


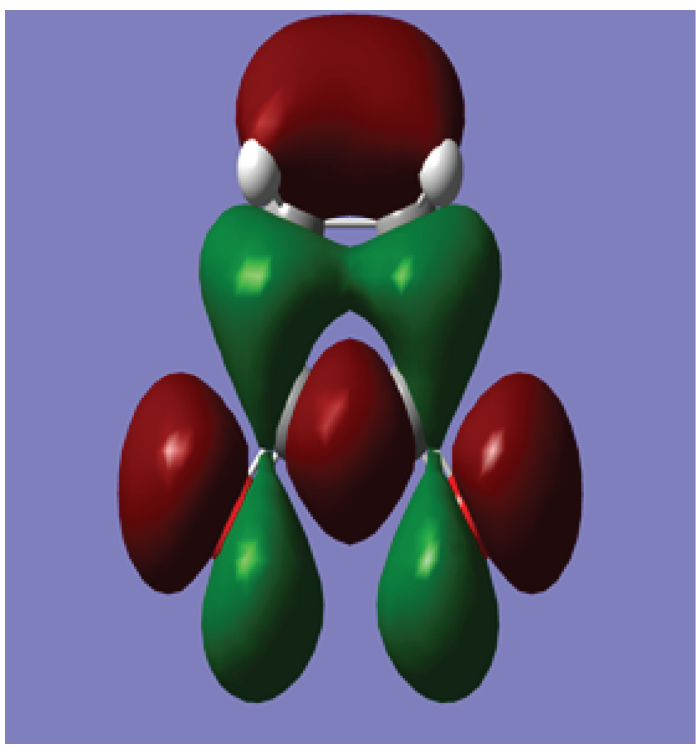

(a)

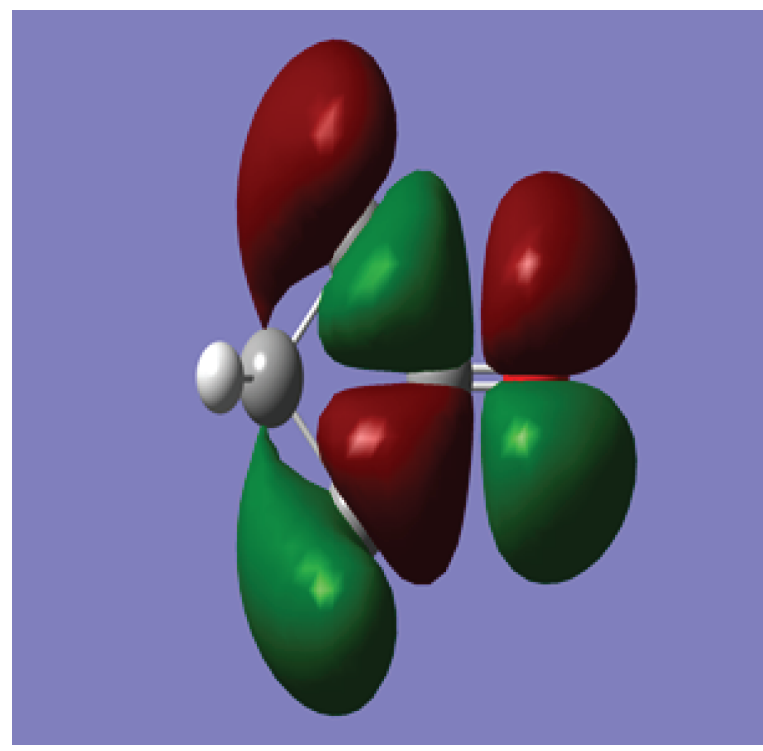

(b)

FIgURE 4: HOMO pictures of 1,2-cyclobutanedione and cyclobutanone.

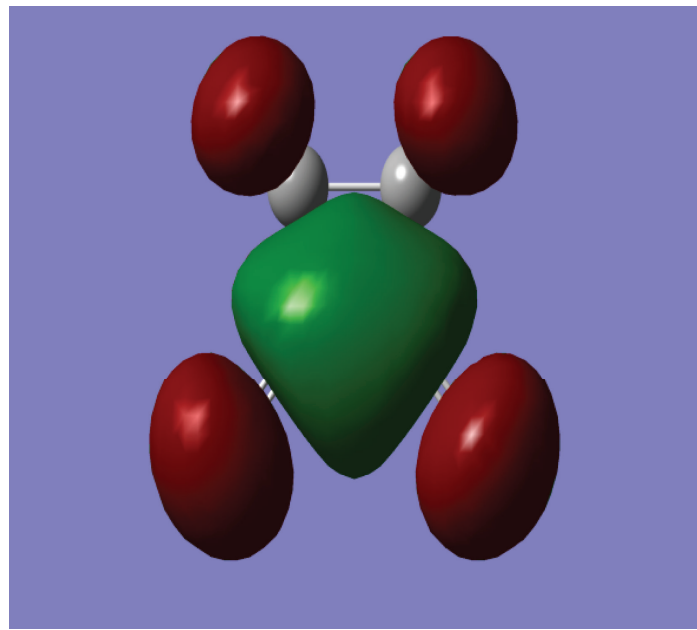

(a)

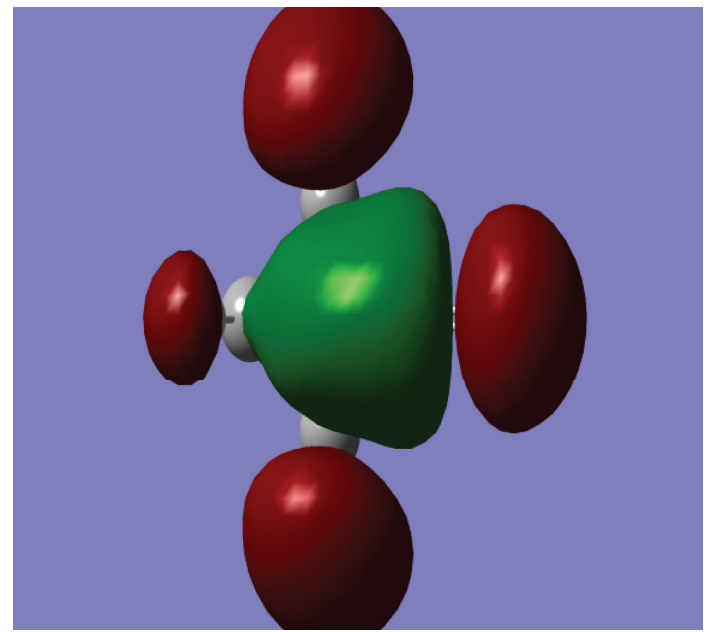

(b)

FIGURE 5: LUMO pictures of 1,2-cyclobutanedione and cyclobutanone.

TABLE 3: Thermodynamic properties and other electronic properties of 1,2-cyclobutanedione and cyclobutanone.

\begin{tabular}{|c|c|c|c|c|c|}
\hline \multirow{2}{*}{ Parameter (unit) } & \multirow{2}{*}{$\begin{array}{c}\text { Cyclobutanone } \\
\text { B3PW91 }\end{array}$} & \multicolumn{4}{|c|}{ 1,2-Cyclobutanedione } \\
\hline & & B3LYP & B3PW91 & MP2 & LSDA \\
\hline Total thermal energy (KCal/Mol) & 60.352 & 48.535 & 48.702 & 49.361 & 47.49 \\
\hline Vibrational energy (Thermal) (KCal/Mol) & 58.574 & 46.758 & 46.925 & 47.584 & 45.713 \\
\hline Entropy $\left(\mathrm{Cal} \mathrm{mol}^{-1} \mathrm{~K}^{-1}\right)$ & 72.372 & 75.111 & 75.133 & 75.345 & 75.779 \\
\hline Rotational energy (Thermal) (KCal/Mol) & 0.889 & 0.889 & 0.889 & 0.889 & 0.889 \\
\hline 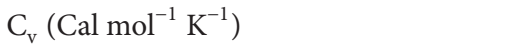 & 16.947 & 19.004 & 18.932 & 18.687 & 19.504 \\
\hline Zero point energy (a.u.) & -231.153 & -305.236 & -305.121 & -304.368 & -303.613 \\
\hline Dipole moment (Debye) & 2.8438 & 3.7114 & 3.7599 & 3.5019 & 3.722 \\
\hline Homo-Lumo $(\mathrm{eV})$ & 6.023 & & 3.889 & & \\
\hline
\end{tabular}


TABLE 4: Atomic charges (e) of the title compounds in gas phase.

\begin{tabular}{lcccccc}
\hline \multicolumn{2}{c}{ Cyclobutanone } & & \multicolumn{3}{c}{ Cyclobutane 1,2-dione } \\
Atom & B3PW91 & Atom & B3LYP & B3PW91 & MP2 & 0.319492 \\
\hline $\mathrm{C}_{1}$ & -0.319556 & $\mathrm{C}_{1}$ & 0.370666 & 0.377876 & 0.377877 & 0.346844 \\
$\mathrm{C}_{2}$ & 0.404371 & $\mathrm{C}_{2}$ & 0.370666 & -0.351817 & -0.330871 & -0.367294 \\
$\mathrm{C}_{3}$ & -0.31811 & $\mathrm{C}_{3}$ & -0.290078 & -0.351817 & -0.330871 & -0.367294 \\
$\mathrm{C}_{4}$ & -0.279564 & $\mathrm{C}_{4}$ & -0.290078 & -0.382319 & -0.339399 & -0.324671 \\
$\mathrm{O}_{5}$ & -0.421139 & $\mathrm{O}_{5}$ & -0.376946 & -0.382319 & -0.339398 & -0.324671 \\
$\mathrm{H}_{6}$ & 0.169047 & $\mathrm{O}_{6}$ & -0.376946 & 0.185352 & 0.154635 & 0.193670 \\
$\mathrm{H}_{7}$ & 0.169788 & $\mathrm{H}_{7}$ & 0.155425 & 0.170909 & 0.168791 & 0.178804 \\
$\mathrm{H}_{8}$ & 0.138391 & $\mathrm{H}_{8}$ & 0.140934 & 0.170909 & 0.168790 & 0.178806 \\
$\mathrm{H}_{9}$ & 0.143736 & $\mathrm{H}_{9}$ & 0.140934 & 0.185351 & 0.154636 \\
$\mathrm{H}_{10}$ & 0.158296 & $\mathrm{H}_{10}$ & 0.155423 & & & 0.193667 \\
$\mathrm{H}_{11}$ & 0.154741 & & & & \\
\hline
\end{tabular}

TABLE 5: Comparison of experimental raman spectra with calculated vibrational wave numbers $\left(\mathrm{cm}^{-1}\right)$ with \% PED contribution of corresponding modes in brackets using different methods and 6-31G $(\mathrm{d}, \mathrm{p})$ basis set combination of 1,2-cyclobutanedione under symmetry consideration.

\begin{tabular}{|c|c|c|c|c|c|c|}
\hline \multirow{2}{*}{ S. no. } & \multirow{2}{*}{ Assignments } & \multirow{2}{*}{ Exp. (Raman values) } & \multicolumn{4}{|c|}{ Calculated } \\
\hline & & & B3LYP & B3PW91 & LSDA & MP2 \\
\hline \multicolumn{7}{|c|}{ For b2 modes } \\
\hline 1 & $v_{\mathrm{as}}\left(\mathrm{CH}_{2}\right)(99)$ & 3011 & 3021 & 3037 & 3114 & 2974 \\
\hline 2 & $v_{\mathrm{as}}(\mathrm{C}-\mathrm{O})(90)$ & 1802 & 1838 & 1852 & 1780 & 1831 \\
\hline 3 & $\gamma(\mathrm{CH})+\mathrm{S}_{\mathrm{a}}\left(\mathrm{CH}_{2}\right)(97)$ & 1382 & 1390 & 1380 & 1431 & 1312 \\
\hline 4 & Ring distortion & 919 & 905 & 923 & 945 & 878 \\
\hline 5 & Ring distortion & 713 & 715 & 715 & 726 & 683 \\
\hline 6 & $\mathrm{R}_{\mathrm{a}}\left(\mathrm{CH}_{2}\right)$ & 287 & 280 & 284 & 287 & 262 \\
\hline 7 & Asym. $(\mathrm{C}-\mathrm{C}=\mathrm{O})$ bending & & 279 & 281 & 282 & 245 \\
\hline \multicolumn{7}{|c|}{ For b1 modes } \\
\hline 8 & $v_{\mathrm{s}}\left(\mathrm{CH}_{2}\right)(99)$ & 2952 & 2963 & 2974 & 3041 & 2912 \\
\hline 9 & $\omega\left(\mathrm{CH}_{2}\right)$ & & 997 & 994 & 1006 & 953 \\
\hline 10 & $\omega\left(\mathrm{CH}_{2}\right)+\omega(\mathrm{C}-\mathrm{C}=\mathrm{O})$ & & 932 & 934 & 955 & 927 \\
\hline 11 & $\omega_{\mathrm{s}}(\mathrm{C}-\mathrm{C}=\mathrm{O})$ & & 696 & 695 & 712 & 631 \\
\hline \multicolumn{7}{|c|}{ For a1 modes } \\
\hline 12 & $v(\mathrm{CH})(100)$ & 2964 & 2969 & 2980 & 3047 & 2917 \\
\hline 13 & $v(\mathrm{C}=\mathrm{O})(95)$ & 1765 & 1792 & 1810 & 1736 & 1786 \\
\hline 14 & Symm. $(\mathrm{CH})$ bending $+\mathrm{s}\left(\mathrm{CH}_{2}\right)(97)$ & 1403 & 1408 & 1401 & 1451 & 1333 \\
\hline 15 & $v(\mathrm{C}-\mathrm{C})$ Ring breathing & & 1161 & 1162 & 1189 & 1118 \\
\hline 16 & Ring distortion & & 1017 & 1030 & 1054 & 1008 \\
\hline 17 & $\mathrm{R}_{\mathrm{s}}\left(\mathrm{CH}_{2}\right)$ & 979 & 935 & 941 & 961 & 928 \\
\hline 18 & Ring distortion & & 700 & 710 & 720 & 673 \\
\hline 19 & Symm. $(\mathrm{C}-\mathrm{C}=\mathrm{O})$ bending & 487 & 495 & 492 & 489 & 448 \\
\hline \multicolumn{7}{|c|}{ For a2 modes } \\
\hline 20 & $v_{\mathrm{as}}\left(\mathrm{CH}_{2}\right)(99)$ & & 3009 & 3025 & 3103 & 2963 \\
\hline 21 & $\mathrm{R}_{\mathrm{a}}\left(\mathrm{CH}_{2}\right)(88)$ & 1210 & 1188 & 1186 & 1210 & 1130 \\
\hline 22 & $\beta(\mathrm{C}-\mathrm{H})(87)$ & 1181 & 1167 & 1166 & 1195 & 1121 \\
\hline 23 & Asym. $(\mathrm{C}-\mathrm{C}=\mathrm{O})$ bending $+\omega\left(\mathrm{CH}_{2}\right)$ & & 517 & 525 & 525 & 497 \\
\hline 24 & Ring twist & & 86 & 82 & 70 & 72 \\
\hline
\end{tabular}




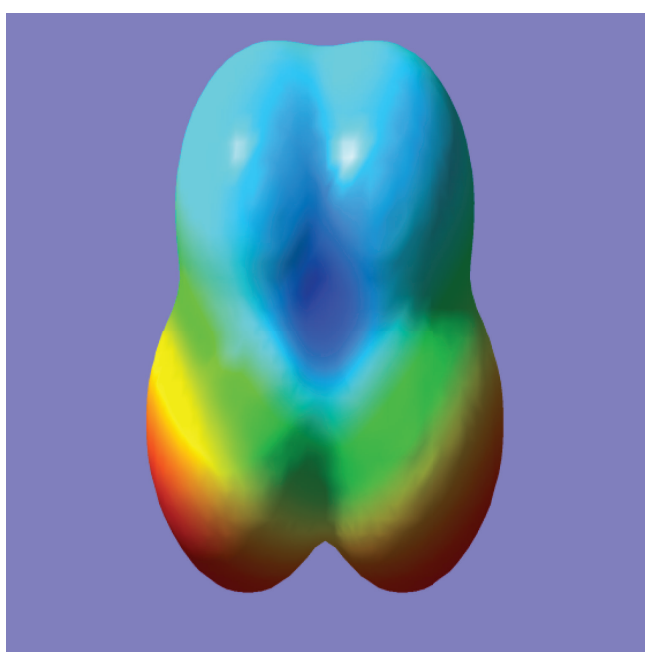

(a)

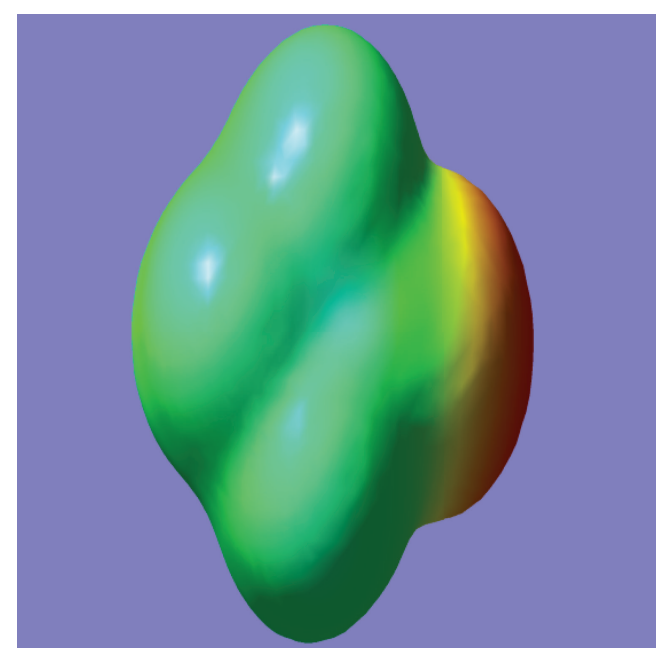

(b)

FIGURE 6: MESP pictures of 1,2-cyclobutanedione and cyclobutanone.

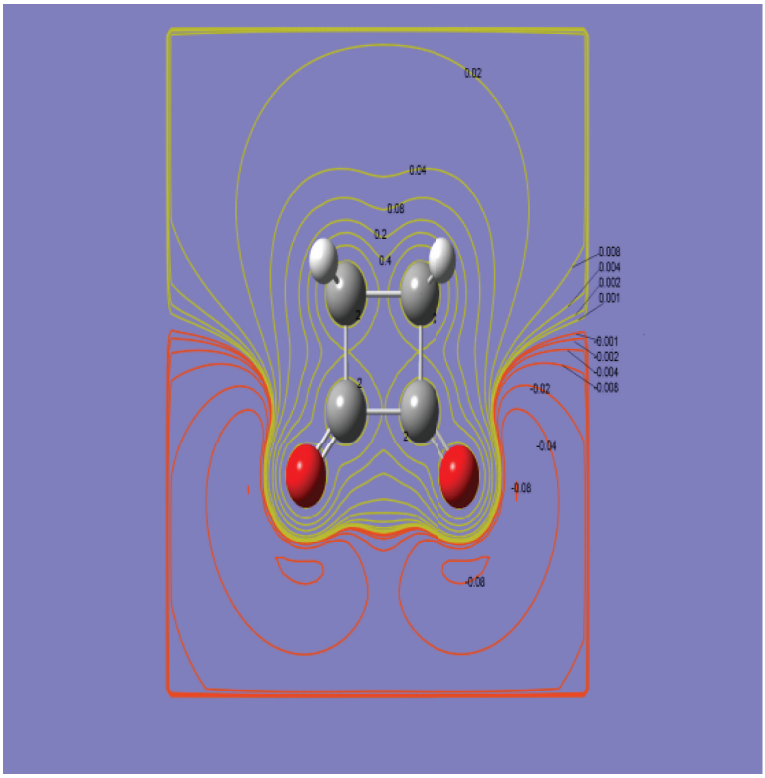

(a)

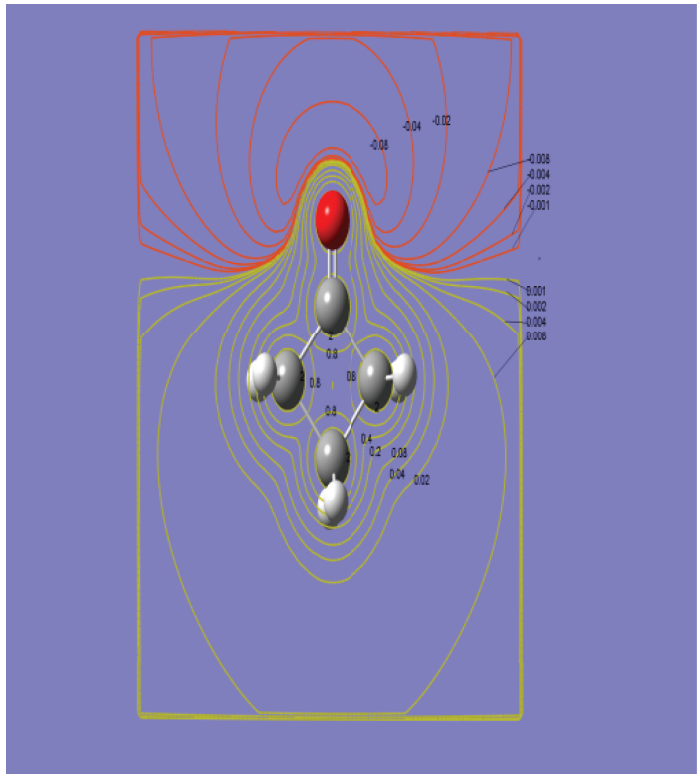

(b)

FIGURE 7: Contour plots of 1,2-cyclobutanedione and cyclobutanone.

3000 and $2900 \mathrm{~cm}^{-1}$, which is the characteristic region for the ready identification of $\mathrm{C}-\mathrm{H}$ stretching vibrations. Accordingly, in the present study for 1,2-cyclobutanedione, the $\mathrm{C}-\mathrm{H}$ stretching vibrations are calculated at $3025 \mathrm{~cm}^{-1}$, $3037 \mathrm{~cm}^{-1}, 2980 \mathrm{~cm}^{-1}$, and $2974 \mathrm{~cm}^{-1}$, respectively, with significant PED and are supported by the experimental data. It can be seen that a less intense polarized (along the plane) and very intense unpolarized Raman peak is observed at the $2952 \mathrm{~cm}^{-1}$ and $2964 \mathrm{~cm}^{-1}$ and their corresponding calculated peaks at $2974 \mathrm{~cm}^{-1}$ and $2980 \mathrm{~cm}^{-1}$, which belongs to the symmetric stretching modes of vibration with the PED of $99 \%$ and $100 \%$, respectively. Another intense Raman mode is observed at $3011 \mathrm{~cm}^{-1}$ with PED contribution of $99 \%$ and their corresponding calculated modes at $3042 \mathrm{~cm}^{-1}$ which is corresponding to antisymmetric stretching in $\mathrm{C}-\mathrm{H}$. In case of 1,2-cyclobutanedione, the $\mathrm{C}-\mathrm{H}$ stretching is at lower value than cyclobutanone, ranging from $3041 \mathrm{~cm}^{-1}$ to $2958 \mathrm{~cm}^{-1}$ and probably this is due to the disubstituted oxygen at the aromatic ring, which extracts more electrons from the ring carbon, thereby causing lower bond strength between carbon and oxygen.

3.5.2. Carbonyl Absorption. Carbonyl absorptions are very sensitive and both the carbon and oxygen atoms of the 
TABLE 6: Comparative study of calculated wave numbers IR intensity and Raman intensity of 1,2-cyclobutanedione and cyclobutanone.

\begin{tabular}{|c|c|c|c|c|c|c|c|c|}
\hline \multirow[t]{2}{*}{ S. no. } & \multicolumn{4}{|c|}{$\begin{array}{c}\text { Cyclobutanone } \\
{[\text { B3PW91/6-31G }(\mathrm{d}, \mathrm{p})]}\end{array}$} & \multicolumn{4}{|c|}{$\begin{array}{l}\text { Cyclobutane 1,2-dione } \\
\text { [B3PW91/6-31G }(\mathrm{d}, \mathrm{p})]\end{array}$} \\
\hline & Sc. freq. & IR int. & Raman activity & Assignments & Sc. freq. & IR int. & Raman activity & Assignments \\
\hline 1 & 42 & 4.11 & 0.33 & O.O.P. ring bending & 82 & 0.00 & 0.04 & Ring twist \\
\hline 2 & 401 & 0.79 & 2.73 & $\gamma(\mathrm{C}-\mathrm{C}=\mathrm{O})$ & 281 & 9.91 & 1.17 & $\mathrm{R}_{\mathrm{a}}\left(\mathrm{CH}_{2}\right)$ \\
\hline 3 & 462 & 3.15 & 4.25 & $\beta(\mathrm{C}-\mathrm{C}=\mathrm{O})$ & 284 & 3.04 & 3.79 & Assy $(\mathrm{C}-\mathrm{C}=\mathrm{O})$ Bending \\
\hline 4 & 623 & 0.00 & 0.01 & $\mathrm{R}\left(\mathrm{CH}_{2}\right)$ & 492 & 1.72 & 1.11 & $\operatorname{Symm}(\mathrm{C}-\mathrm{C}=\mathrm{O})$ Bending \\
\hline 5 & 678 & 1.78 & 5.02 & Ring deformation & 525 & 0.00 & 0.12 & Assy $(\mathrm{C}-\mathrm{C}=\mathrm{O})$ Bending $+\omega\left(\mathrm{CH}_{2}\right)$ \\
\hline 6 & 743 & 5.35 & 0.98 & $\mathrm{R}\left(\mathrm{CH}_{2}\right)$ & 695 & 8.77 & 0.03 & $\omega(\mathrm{C}-\mathrm{C}=\mathrm{O})$ \\
\hline 7 & 819 & 1.22 & 3.50 & Ring deformation & 710 & 0.02 & 13.62 & Ring deformation \\
\hline 8 & 912 & 0.34 & 10.67 & Ring deformation & 715 & 14.04 & 4.52 & Ring deformation \\
\hline 9 & 920 & 0.16 & 1.82 & $\tau\left(\mathrm{CH}_{2}\right)$ & 923 & 17.82 & 9.59 & Ring deformation \\
\hline 10 & 950 & 2.09 & 19.67 & Ring deformation & 934 & 0.18 & 6.77 & $\omega\left(\mathrm{CH}_{2}\right)+\omega(\mathrm{C}-\mathrm{C}=\mathrm{O})$ \\
\hline 11 & 1057 & 0.76 & 0.14 & Ring deformation & 941 & 46.62 & 2.44 & $\mathrm{R}_{\mathrm{s}}\left(\mathrm{CH}_{2}\right)$ \\
\hline 12 & 1060 & 93.41 & 0.09 & $\mathrm{R}\left(\mathrm{CH}_{2}\right)$ & 994 & 0.01 & 0.01 & $\omega\left(\mathrm{CH}_{2}\right)$ \\
\hline 13 & 1150 & 3.96 & 4.18 & $\omega\left(\mathrm{CH}_{2}\right)$ & 1030 & 113.97 & 5.36 & Ring deformation \\
\hline 14 & 1179 & 0.32 & 13.69 & $\tau\left(\mathrm{CH}_{2}\right)$ & 1162 & 0.35 & 3.23 & $v(\mathrm{C}-\mathrm{C})+$ Ring breathing \\
\hline 15 & 1183 & 0.85 & 7.73 & $\tau\left(\mathrm{CH}_{2}\right)$ & 1166 & 0.00 & 0.88 & $\beta(\mathrm{CH})$ \\
\hline 16 & 1201 & 5.46 & 0.63 & $\omega\left(\mathrm{CH}_{2}\right)$ & 1186 & 0.00 & 0.61 & $\mathrm{R}_{\mathrm{a}}\left(\mathrm{CH}_{2}\right)$ \\
\hline 17 & 1232 & 9.55 & 0.12 & $\omega\left(\mathrm{CH}_{2}\right)$ & 1380 & 4.44 & 14.64 & $\gamma(\mathrm{CH})+\mathrm{R}_{\mathrm{a}}\left(\mathrm{CH}_{2}\right)$ \\
\hline 18 & 1380 & 17.91 & 1.04 & $\delta\left(\mathrm{CH}_{2}\right)$ & 1401 & 21.5 & 11.38 & $\mathrm{~S}\left(\mathrm{CH}_{2}\right)+\beta(\mathrm{CH})$ \\
\hline 19 & 1394 & 1.23 & 29.08 & $\delta\left(\mathrm{CH}_{2}\right)$ & 1810 & 237.45 & 84.26 & $v(\mathrm{C}=\mathrm{O})$ \\
\hline 20 & 1449 & 0.85 & 9.37 & $\delta\left(\mathrm{CH}_{2}\right)$ & 1852 & 118.39 & 56.88 & $v(\mathrm{C}=\mathrm{O})$ \\
\hline 21 & 1837 & 277.65 & 10.79 & $v(\mathrm{C}=\mathrm{O})$ & 2974 & 6.84 & 83.45 & $v_{s}(\mathrm{CH})$ \\
\hline 22 & 2964 & 12.36 & 4.03 & $v_{\mathrm{s}}\left(\mathrm{CH}_{2}\right)$ & 2980 & 0.13 & 74.57 & $v_{s}(\mathrm{CH})$ \\
\hline 23 & 2968 & 8.31 & 189.8 & $v_{s}\left(\mathrm{CH}_{2}\right)$ & 3025 & 0.00 & 67.84 & $v_{\mathrm{as}}\left(\mathrm{CH}_{2}\right)$ \\
\hline 24 & 2990 & 23.03 & 124.08 & $v_{\mathrm{s}}\left(\mathrm{CH}_{2}\right)$ & 3037 & 4.30 & 72.59 & $v_{\mathrm{as}}\left(\mathrm{CH}_{2}\right)$ \\
\hline 25 & 3017 & 3.68 & 19.04 & $v_{\mathrm{a}}\left(\mathrm{CH}_{2}\right)$ & & & & \\
\hline 26 & 3022 & 1.19 & 136.71 & $v_{\mathrm{a}}\left(\mathrm{CH}_{2}\right)$ & & & & \\
\hline 27 & 3047 & 23.07 & 58.28 & $v_{\mathrm{a}}\left(\mathrm{CH}_{2}\right)$ & & & & \\
\hline
\end{tabular}

$\nu$ : Stretching; $v_{s}$ : symmetric stretching; $v_{\text {as }}$ : asymmetric stretching; $\beta$ : in-plane bending; $\gamma$ : out-of-plane bending; $\omega$ : wagging; $\tau$ : torsion; int: intensity.

carbonyl group move during the vibration and they have a nearly equal amplitude. At some lower range of frequency, two peaks one medium and the other intense are calculated at $1852 \mathrm{~cm}^{-1}$ and $1810 \mathrm{~cm}^{-1}$ with PED contribution of $90 \%$ and 95\% at B3PW91 level, and the corresponding experimental Raman frequencies are at $1802 \mathrm{~cm}^{-1}$ and $1765 \mathrm{~cm}^{-1}$, which are weak in intensity. These modes are corresponding to antisymmetric stretching and symmetric stretching in $\mathrm{C}=\mathrm{O}$. As it can be seen, there are a lot of discrepancies created in $\mathrm{C}=\mathrm{O}$ stretching modes between experimental and calculated method using different levels of theories. There is no appropriate answer for this; perhaps these discrepancies are due to the intermolecular interaction between more electronegative oxygen and less electronegative hydrogen and also antibonding repulsion between carbon and oxygen atoms. The $\mathrm{C}=\mathrm{O}$ stretching vibration which is observed at
$1837 \mathrm{~cm}^{-1}$ for cyclobutanone and is at a lower value than $1,2-$ cyclobutanedione.

3.5.3. Some Other Modes of Vibration. At lower frequencies a Raman peak is observed at $287 \mathrm{~cm}^{-1}$ and their corresponding calculated modes having low intensity are calculated at $284 \mathrm{~cm}^{-1}$ at B3PW91 level, which is due to antisymmetric $\mathrm{CH}_{2}$ rocking parallel to the plane of ring. In the lower region another two intense Raman peaks are observed at $919 \mathrm{~cm}^{-1}$ and $713 \mathrm{~cm}^{-1}$, and their corresponding calculated modes of low intensity are found at $923 \mathrm{~cm}^{-1}$ and $715 \mathrm{~cm}^{-1}$ by B3PW91 method, which is due to the symmetric bending in plane and perpendicular to the plane of ring, respectively. However, in cyclobutanone their corresponding ring deformation is calculated at $1057 \mathrm{~cm}^{-1}$ and $678 \mathrm{~cm}^{-1}$, respectively. A low 
intense Raman peak is observed at $487 \mathrm{~cm}^{-1}$ and its corresponding calculated value is $492 \mathrm{~cm}^{-1}$, at B3PW91 level, which corresponds to symmetric in plane $\mathrm{C}-\mathrm{C}=\mathrm{O}$ bending and their corresponding $\mathrm{C}-\mathrm{O}$ bending in cyclobutanone is calculated at $462 \mathrm{~cm}^{-1}$. In between the two Raman peaks $\left(1765 \mathrm{~cm}^{-1}\right.$ and $\left.919 \mathrm{~cm}^{-1}\right)$ some medium and weak peaks are also observed. Medium peaks are corresponding to antisymmetric scissoring of $\mathrm{C}-\mathrm{H}$, perpendicular to the plane of cycloring. Besides it, in the lower modes of vibration some mixing of modes of vibration, for example, asymmetric $\mathrm{C}-\mathrm{C}=\mathrm{O}$ bending, and wagging perpendicular to the plane and ring twist, appears at very low Raman and IR intensity. At lower range of frequencies some discrepancies are observed in the experimental intensity and theoretical intensity. This is due to the impurity of the sample taken, intermolecular interaction, anharmonicity, mixing of different modes of vibrations.

3.6. Electronic Properties. The interaction with other species in a chemical system is also determined by frontier orbitals, HOMO and LUMO. It can also be determined by experimental data. The frontier orbital gap helps to distinguish the chemical reactivity and kinetic stability of the molecule. A molecule which has a larger orbital gap is more polarized having more reactive part as far as reaction is concerned [27]. The frontier orbital gap in case of the given molecules is 3.823 and $5.871 \mathrm{eV}$, respectively, for 1,2-cyclobutanedione and cyclobutanone given in Table 7 . Since we are concerned with electronic reactivity here and so it can be said that 1,2cyclobutanedione is more reactive.

The contour plots of the HOMO, LUMO, and electrostatic potential for both the molecules are shown in Figures 4, 5,6 , and 7. The importance of MESP lies in the fact that it simultaneously displays molecular size, shape as well as positive, negative, and neutral electrostatic potential regions in terms of colour grading and is very useful in the investigation of molecular structure with its physiochemical property relationship [28-32]. For 1,2-cyclobutanedione and cyclobutanone, the electronegative region is outside of the molecule near the oxygen atoms. The energy equal to the shielded potential energy surface is required for any substitution reaction near the oxygen atom. The electronegative lines (in between -0.08 a.u. and -0.02 a.u.) form a closed contour which clearly indicates that total flux passing in between these curves is not equal to zero. For any nucleophilic substitution reaction near oxygen (closed contour area), an amount of energy equal to the shielded potential energy surface is required; however remaining part of the molecule is suitable for electrophilic substitution reaction. Thus it can be asserted that MESP values have been shown to be well related to the biological properties [33-35].

\section{Conclusions}

All frequencies are real in both the molecules. Hence, both the compounds are stable. All calculations are done on a single molecule, so we ignore intermolecular forces, that is,
TABLE 7: HOMO-LUMO gap (Frontier orbital energy gap) and Dipole Moment of 1,2-cyclobutanedione and cyclobutanone by (B3PW91)/6-31G (d p) methods.

\begin{tabular}{lcc}
\hline Parameters & Cyclobutane 1,2 dione & Cyclobutanone \\
\hline HOMO & -6.900 & -6.709 \\
LUMO & -3.077 & -0.838 \\
Energy gap & 3.823 & 5.871 \\
$\begin{array}{l}\text { Dipole moment } \\
\text { (in debye) }\end{array}$ & 4.831 & 3.603 \\
\hline
\end{tabular}

van der Waals molecule-molecule interaction. These interactions produce perturbation in energy levels resulting in the increase or decrease of energy levels. As seen from Table 3, thermal energy calculated by MP2 and B3PW91 methods gave higher value while LSDA gave the lowest value; however, in the case of entropy the opposite trend is obtained.

Among all methods, B3PW91 hybrid functional, applied to density functional force fields with a 6-31G (d, p) basis set most successfully described the vibrational spectra of both 1,2-cyclobutanedione and cyclobutanone. The lower value of frontier orbital energy gap and a higher dipole moment in case of 1,2-cyclobutanedione suggest a more reactive nature as compared to cyclobutanone.

\section{References}

[1] http://www.britannica.com/EBchecked/topic/278321/hydrocarbon/277893/Cycloalkanes.

[2] http://www.westminster.edu/staff/Kailbw/CH2b.pdf.

[3] J. S. Sinninghe Damsté, M. Strous, W. I. C. Rijpstra et al., "Linearly concatenated cyclobutane lipids form a dense bacterial membrane," Nature, vol. 419, no. 6908, pp. 708-712, 2002.

[4] V. Mascitti and E. J. Corey, "Enantioselective synthesis of pentacycloanammoxic acid," Journal of the American Chemical Society, vol. 128, no. 10, pp. 3118-3119, 2006.

[5] J. A. Pople, H. B. Schlegel, R. Krishnan et al., "Molecular orbital studies of vibrational frequencies," International Journal of Quantum Chemistry, vol. 15, pp. 269-278, 1981.

[6] J. A. Pople, A. P. Scott, M. W. Wong, and L. Radom, "Scaling factors for obtaining fundamental vibrational frequencies and zero-point energies from $\mathrm{HF} / 6-31 \mathrm{G}^{*}$ and $\mathrm{MP} 2 / 6-31 \mathrm{G}^{*}$ harmonic frequencies," Israel Journal of Chemistry, vol. 33, pp. 345-350, 1993.

[7] A. D. Becke, "Density-functional thermochemistry. III. The role of exact exchange," The Journal of Chemical Physics, vol. 98, no. 7, pp. 5648-5652, 1993.

[8] B. B. Laird, R. B. Ross, and R. B. Zeigler, Chemical Applications of Density Functional Theory, ACS Symposium Series 629, American Chemical Society, Washington, DC, USA, 1996.

[9] M. J. Frisch, G. W. Trucks, H. B. Schlegel et al., GAUSSIAN 09, Revision B.01, Gaussian, Wallingford, Conn, USA, 2009.

[10] H. B. Schlegel, "Optimization of equilibrium geometries and transition structures," Journal of Computational Chemistry, vol. 3, no. 2, pp. 214-218, 1982.

[11] N. Sundaraganesan, H. Saleem, S. Mohan, M. Ramalingam, and V. Sethuraman, "FTIR, FT-Raman spectra and ab initio DFT vibrational analysis of 2-bromo-4-methyl-phenylamine," Spectrochimica Acta, vol. 62, no. 1-3, pp. 740-751, 2005. 
[12] M. H. Jamroz, Vibrational Energy Distribution Analysis, VEDA 4 Program, Warsaw, Poland, 2004.

[13] A. Frisch, A. B. Nelson, and A. J. Holder, GAUSSVIEW User Manual, Gaussian Inc, Pittsburgh, Pa, USA, 2000.

[14] F. Takabayashi, H. Kambara, and K. Kuchitau, "Density Functional Thermochemistry. III. The role of exact exchange," in 7th Austin Symposium of Gas Phase Molecular Structure, Austin, Tex, USA, March 1978, Paper WA6.

[15] M. Kurt and S. Yurdakul, "Molecular structure and vibrational spectra of 1,2-bis(4-pyridyl) ethane by density functional theory and ab initio Hartree-Fock calculations," Journal of Molecular Structure, vol. 654, no. 1-3, pp. 1-9, 2003.

[16] S. H. Lee, Y. Kim, D. S. Kim, and K. Seff, "Crystal structure of dehydrated $\mathrm{Rb}^{+}$-exchanged zeolite $\mathrm{X}, \mathrm{Rb}_{71} \mathrm{Na}_{21} \mathrm{Si}_{100} \mathrm{Al}_{92} \mathrm{O}_{384}$, ” Bulletin of the Korean Chemical Society, vol. 19, no. 1, pp. 98-103, 1998.

[17] S. Y. Lee and B. H. Boo, "Molecular structures and vibrational spectra of pyrrole and carbazole by density functional theory and conventional ab Initio calculations," The Journal of Physical Chemistry, vol. 100, no. 37, pp. 15073-15078, 1996.

[18] S. Y. Lee and B. H. Boo, "Density functional theory study of vibrational spectra of fluorene," The Journal of Physical Chemistry, vol. 100, no. 21, pp. 8782-8785, 1996.

[19] T. Iijima, "Molecular structure of propane," Bulletin of the Chemical Society of Japan, vol. 45, pp. 1291-1294, 1972.

[20] W. F. Bradford, S. Fitzwater, and L. S. Bartell, "Molecular structure of n-butane: calculation of vibrational shrinkages and an electron diffraction re-investigation," Journal of Molecular Structure, vol. 38, pp. 185-194, 1977.

[21] L. S. Bartell and D. A. Kohl, "Structure and rotational isomerization of free hydrocarbon chains," The Journal of Chemical Physics, vol. 39, no. 11, pp. 3097-3105, 1963.

[22] L. S. Bartell and R. A. Bonham, "Structure of isobutylene," The Journal of Chemical Physics, vol. 32, no. 3, pp. 824-826, 1960.

[23] C. Kato, S. Konaka, T. Iiiima, and M. Kimura, "Electron diffraction studies of formaldehyde, acetaldehyde and acetone," Bulletin of the Chemical Society of Japan, vol. 42, no. 8, pp. 2148-2158, 1969.

[24] L. S. Bartell and H. K. Higginbotham, "Electron diffraction study of the structures of ethane and deuteroethane," The Journal of Chemical Physics, vol. 42, no. 3, pp. 851-856, 1965.

[25] R. Betz and P. Klufers, "Cyclobutane-1, 2-dione," Acta Crystallographica, vol. 63, Article ID 03981, 2007.

[26] http://www.sigmaaldrich.com/spectra/rair/RAIR009454.PDF.

[27] I. Fleming, Frontier Orbitals and Organic Chemical Reactions, John Wiley \& Sons, New York, NY, USA, 1976.

[28] J. S. Murray and K. Sen, Molecular Electrostatic Potentials, Concepts and Applications, Elsevier, Amsterdam, The Netherlands, 1996.

[29] I. Alkorta and J. J. Perez, "Molecular polarization potential maps of the nucleic acid bases," International Journal of Quantum Chemistry, vol. 57, no. 1, pp. 123-135, 1996.

[30] E. Scrocco and J. Tomasi, Advances in Quantum Chemistry, Edited by P. Lowdin, Academic Press, NewYork, NY, USA, 1978.

[31] F. J. Luque, M. Orozco, P. K. Bhadane, and S. R. Gadre, "SCRF calculation of the effect of hydration on the topology of the molecular electrostatic potential," Journal of Physical Chemistry, vol. 97, no. 37, pp. 9380-9384, 1993.
[32] J. Šponer and P. Hobza, "DNA base amino groups and their role in molecular interactions: $\mathrm{Ab}$ initio and preliminary density functional theory calculations," International Journal of Quantum Chemistry, vol. 57, no. 5, pp. 959-970, 1996.

[33] M. Bohl, K. Ponsold, and G. Reck, "Quantitative structureactivity relationships of cardiotonic steroids using empirical molecular electrostatic potentials and semiempirical molecular orbital calculations," Journal of Steroid Biochemistry, vol. 21, no. 4, pp. 373-379, 1984.

[34] D. F. V. Lewis and V. S. Griffiths, "Molecular electrostatic potential energies and methylation of DNA bases: a molecular orbital-generated quantitive structure-activity relationship," Xenobiotica, vol. 17, no. 6, pp. 769-776, 1987.

[35] A. Kumar and P. C. Mishra, "Structure-activity relationships for some anti-HIV drugs using electric field mapping," Journal of Molecular Structure, vol. 277, pp. 299-312, 1992. 

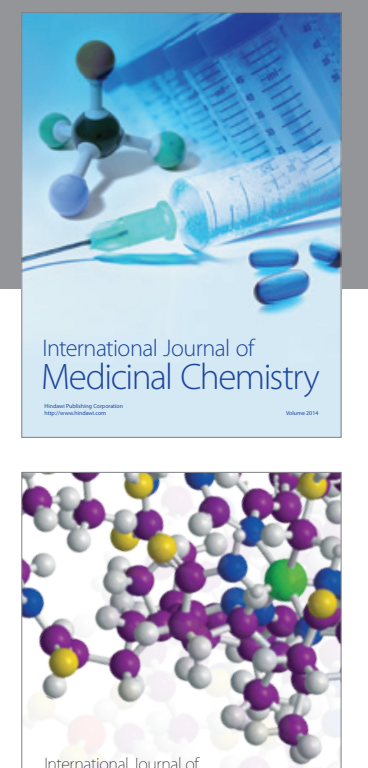

\section{Carbohydrate} Chemistry

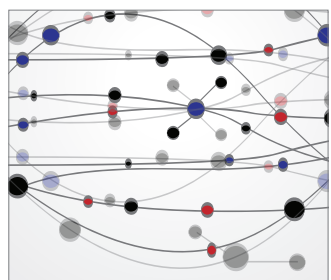

The Scientific World Journal
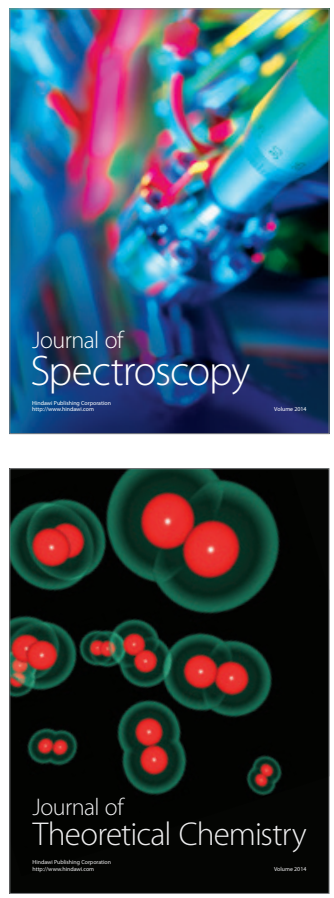
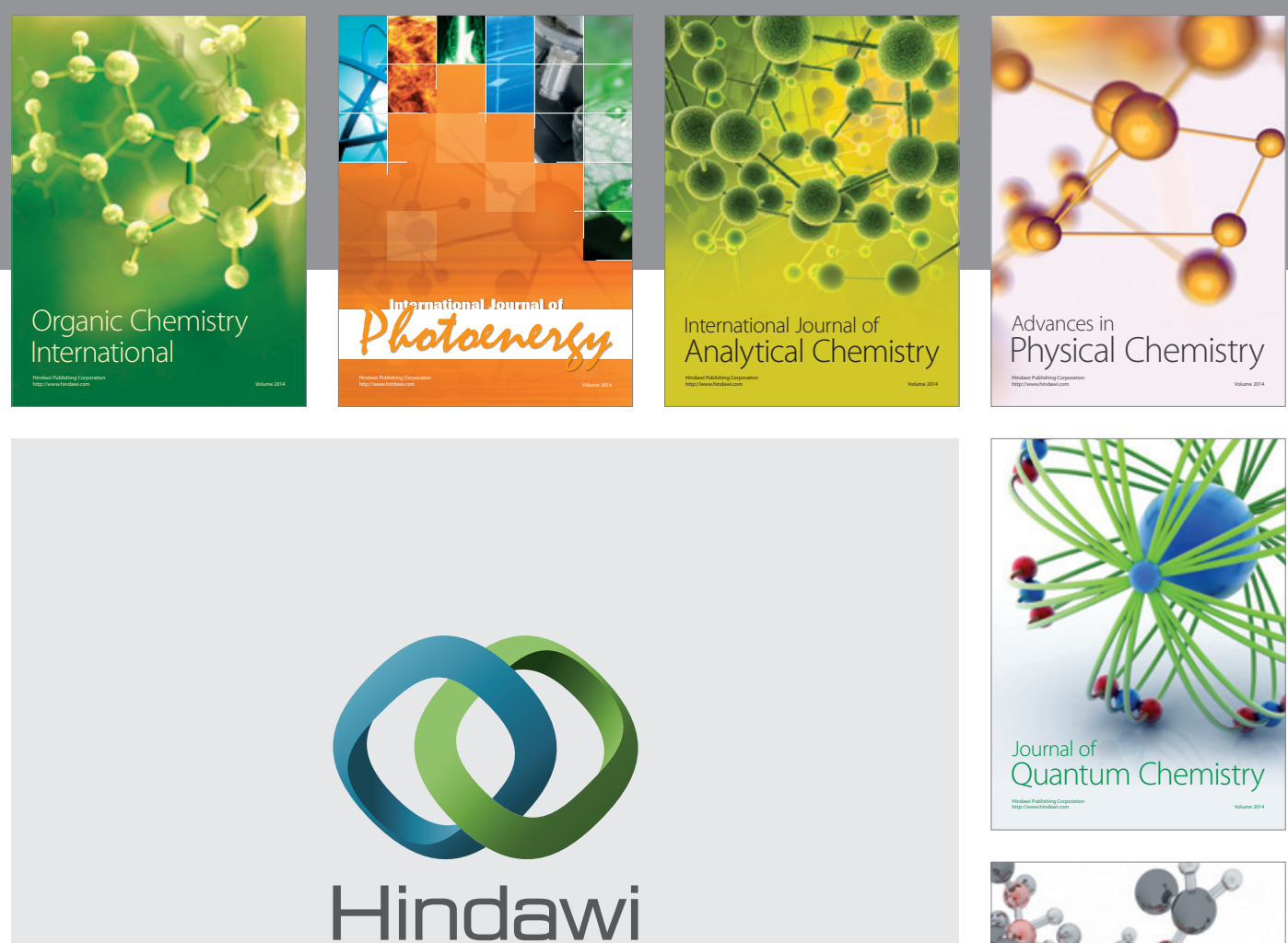

Submit your manuscripts at

http://www.hindawi.com

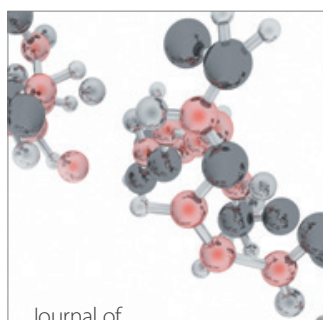

Analytical Methods

in Chemistry

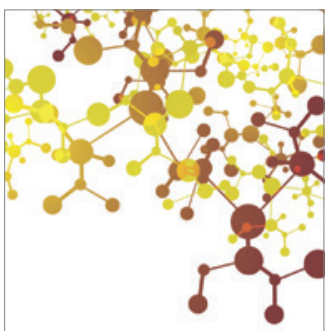

Journal of

Applied Chemistry

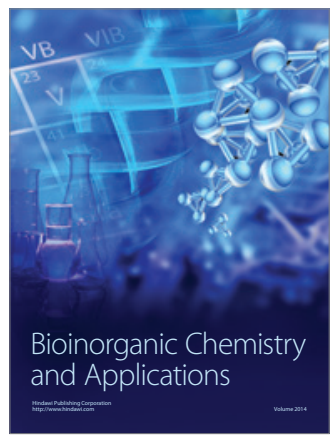

Inorganic Chemistry
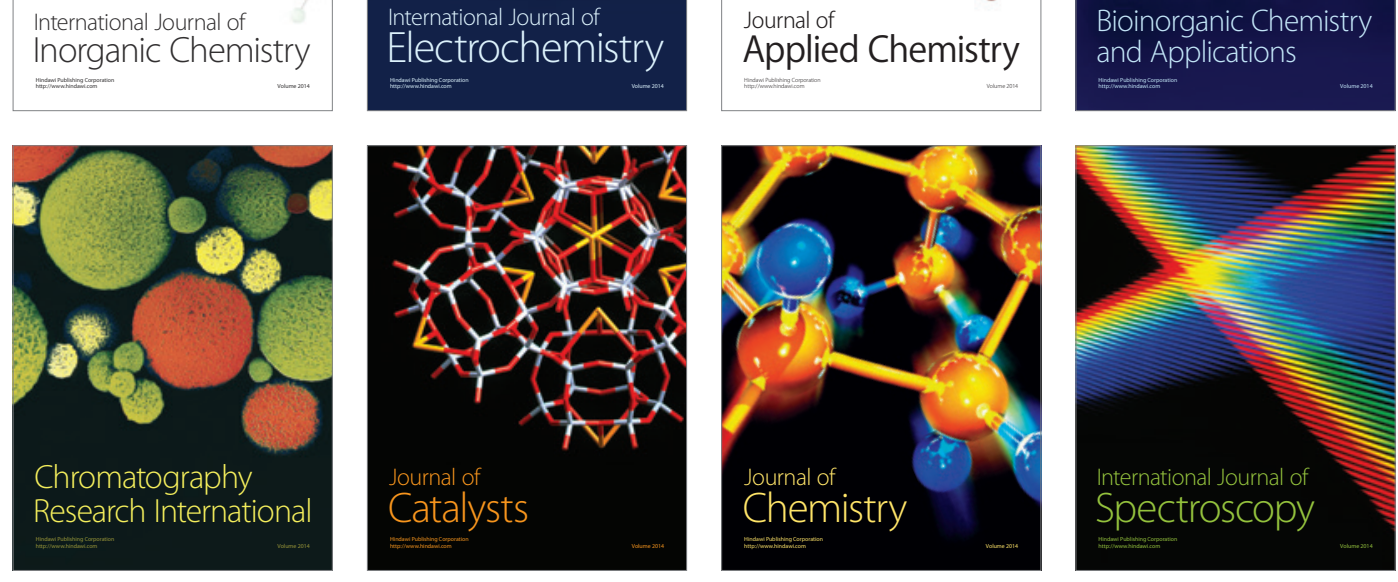